\title{
Phytotoxic effect of paper pulp sludge on Alfisol soil
}

\author{
D. Ríos ${ }^{1 *}$, C. Pérez ${ }^{1}$, M. Sandoval ${ }^{2}$ \\ ${ }^{1}$ Área Medio Ambiente, Unidad de Desarrollo Tecnológico, Universidad de Concepción, Av. Cordillera 2634, \\ Parque Industrial - Coronel, Chile. ${ }^{2}$ Departamento de Suelos y Recursos Naturales, Facultad de Agronomía, \\ Universidad de Concepción, Av. Vicente Méndez 595, Chillán, Chile. 'Corresponding author: d.rios@udt.cl
}

\begin{abstract}
The aim of this study was to evaluate the phytotoxicity of different doses of paper pulp sludge on Alfisol soil in order to determine the potential use of the sludge as a soil improver. The organic waste was physically and chemically characterized to determine the presence of nutrients and heavy metals which is important for plant growth. The germination index (GI), the radicle length and the hypocotyl length of Lactuca sativa L. and Lolium perenne L. were evaluated for six doses of sludge/ soil: 10, 25, 50, 75, 100 and $150 \mathrm{tha}^{-1}$. A control without waste addition was also included. Results indicated low concentration of heavy metals in the sludge which is reflected in the non-toxic effect on seed germination. GI in Lactuca sativa L. reached a maximum in the control with $155 \%$; however, there were no significant differences among the treatments. GI in Lolium perenne $\mathrm{L}$. had the highest value at a dose of $50 \mathrm{t} \mathrm{ha}^{-1}$ with $143 \%$, indicating significant differences between the treatments. The use of paper pulp sludge as a soil improver could be beneficial given the nutrient concentration, the low concentration of heavy metals and the no toxic effect depending on the species treated.
\end{abstract}

Keywords: paper pulp sludge, phytotoxicity, germination. 


\section{Introduction}

By the year 2004, Chile became the fifth largest exporter of paper pulp with a production of 2.5 million tons per year (Luraschi, 2005). The production in the country has increased in recent years with a rate of 4.94 million tons per year by $2008^{1}$. Considering that this industry is continuously growing, the need to find an ecological solution for waste generation is imperative, especially when the prospective trend indicates that the world demand for this product will increase.

Paper pulp sludge contains organic matter and several nutrients such as $\mathrm{Fe}, \mathrm{Ca}$, and $\mathrm{P}$, which are very important in plant growth: It presents high $\mathrm{pH}$ values $(>7.0)$ indicating lower acidity which affects nutrient availability for plants and microorganism; has adequate porosity benefiting damaged soils which lack nutrients; and improves the porosity of the soil which influences the soil's ability to maintain moisture (Esparza, 2004). Moreover in Chile, the susceptibility to accelerated erosion and the high rate of its occurrence depend mainly on land use, favored by rugged geomorphology, climate, soil properties and the nature of vegetation cover, the growth of intense agricultural activities, applied fertilizers and pesticides, and forest activities (Ellies, 2000; Flores et al., 2010). The forest activities include burning of native vegetation across large areas, resulting in soil erosion extending beyond the elimination of valuable topsoil and loss of natural nutrients (Ellies, 2000; Flores et al., 2010). In 1979, erosion affected $46 \%$ of the total country (Pérez and González, 2001), and in 2010 the problem amplified to $49.1 \%{ }^{2}$. Regarding the studied soil located in the Maule Region, erosion in this area is around $48.7 \%$, representing 1.48 million hectares of soil surface with some degree of damage (Flores et al., 2010).
Several countries such as Austria, Finland and France have laws that authorize the reuse of sludge from the pulp and paper making process in land spreading, agriculture and forestry (Gendebien et al., 2000). The idea was borne out of the need to utilize waste and minimize its disposal in landfills in order to decrease contamination and firm's costs. Mandates obliging prior treatment of waste before dumping will ameliorate the aforementioned problems associated with waste disposal (Gendebien et al., 2000). Consequently, as an alternative to discarding potentially reusable paper pulp waste, the initiative to use it to treat damaged soil is presented. Previously reported results demonstrated the possibility to use paper mill sludge as fertilizer in agricultural and forest soils, taking advantage of the high content of nutrients and organic matter in the sludge, its $\mathrm{pH}$-regulator capacity and its porosity which permit the amendment of destruction caused by erosion (Honorato and Bonomelli, 2002).

In Chile, paper pulp sludge has been studied as a volcanic soil amender, with results indicating this waste is a potential soil improver (Aravena et al., 2007; Gallardo et al., 2007; Gallardo et al., 2009; Gallardo et al., 2010). The use of municipal sludge, salmon manure from pisciculture and from lake-cage farming on different types of soils have also being studied (Celis et al., 2007; Sandoval et al., 2010; Sandoval et al., 2011; Celis et al., 2011). In addition to the above-mentioned studies, this paper focuses on the use of paper pulp sludge in Alfisol soil. However, there are several concerns regarding this optional soil amender, as it must be proved that the sludge does not contain hazardous compounds such as resin acids and resin acid neutrals, or high concentrations of heavy

http://www.papelnet.cl/celulosa/12.html

http://www.ciren.cl/web/content.php?i=91 
metals such as arsenic, cadmium, copper, mercury, nickel, lead, selenium and zinc which could limit soil application. Furthermore, the waste must not be dangerous for crops and forest plantations, nor be harmful to humans, animals or the environment (Fraser et al., 2009). Thus, characterization of the sludge prior to use is emphasized. Chile has no regulations regarding the direct use of this organic waste; nevertheless, paper pulp sludge can be reused via composting only in accordance with the Chilean composting regulations.

Given the need of an amender for eroded soils in Chile and the need to reuse waste to fertilize and protect the soil surface, this research was conducted towards determining the potential use of paper sludge as a soil improver through evaluations using bioassays tests on Lactuca sativa L (lettuce) and Lolium perenne L. (ryegrass) in degraded Alfisol soil.

\section{Material and methods}

\subsection{Pulp sludge and soil samples}

A primary paper pulp sludge sample was obtained from treated, non-bleached, Kraft mill wastewater, which was deposited in a pre-disposal pool belonging to a Kraft paper pulp production enterprise. The samples were taken in 25 subgroups at different depths in each of the four sides of a rectangular collection pool, obtaining a total of four subsamples. These four samples where then homogenized and treated as one sludge sample.

Soil samples were taken from the surface at a depth of $20 \mathrm{~cm}$ of granithic and degraded soil, which was identified as Alfisol soil, in a zone located $7 \mathrm{~km}$ from Cauquenes ( $35^{\circ} 97 \mathrm{~S}, 72^{\circ} 24 \mathrm{~W}$ ), corresponding to a sub-humid Mediterranean zone with annual precipitation averaging $695 \mathrm{~mm}$, concentrated in fall and winter; the annual average temperature is $14.7^{\circ} \mathrm{C}$, with a minimum of $4.7^{\circ} \mathrm{C}$ in July and a maximum of $27^{\circ} \mathrm{C}$ in January (Del Pozo and Del Canto, 1999). The soil used in this study was taxonomically classified as Mollic Palexeralfs (CIREN, 1994), a clayey textured soil, with high slopes (>15\%) and $1.4 \mathrm{~g} \mathrm{~cm}^{-3}$ bulk density.

\subsection{Toxicity bioassays}

Tests were performed using six treatments consisting of different doses of sludge added to the soil: $\mathrm{T}_{1}=$ $10 \mathrm{t} \mathrm{ha}^{-1} ; \mathrm{T}_{2}=25 \mathrm{t} \mathrm{ha}^{-1} ; \mathrm{T}_{3}=50 \mathrm{tha}^{-1} ; \mathrm{T}_{4}=75 \mathrm{t} \mathrm{ha}^{-1}$; $\mathrm{T}_{5}=100 \mathrm{t} \mathrm{ha}^{-1} ; \mathrm{T}_{6}=150 \mathrm{t} \mathrm{ha}^{-1}$; a control (containing soil in distilled water and no sludge added) AS and a positive control, to assure total seed inhibition with $0.001 \mathrm{M} \mathrm{Zn}$ (II), were considered. Since there exist no normative towards applying pulp paper sludge in soil, the one to apply water waste sludge in soil which permits a maximum of $90 \mathrm{tha}^{-1}$ per year of sludge in soil, depending on $\mathrm{pH}$ an heavy metals, was used as a reference. However in this experiment it was also desired to find a response to lower, medium and high doses, a reason for setting the parameters between 10 and $150 \mathrm{t} \mathrm{ha}^{-1}$. The treatments and the soil control were homogenized, packaged in plastic bags and incubated in a chamber (in order to stabilize the sludge) with automatically controlled temperature $\left(25 \pm 2{ }^{\circ} \mathrm{C}\right)$ and humidity (60-70\%) for a period of 15 days. This stabilization process is needed to reduce the organic matter decomposition rate, humidity and to avoid microorganism proliferation (Jokela et al., 1997).

Bioassays were performed after the incubation period on diluted extracts of $1: 10$ ratio (50 g sludge: 500 $\mathrm{mL}$ distilled water) of each sludge/soil treatment and 
controls, as described by Sobrero and Ronco (2004). A single layer of 30 seeds of Lactuca sativa $\mathrm{L}$. were placed in a covered $10 \mathrm{~cm}$ Petri dish on Whatman $\mathrm{N}^{\circ}$ 3 filter paper previously moistened with $5 \mathrm{~mL}$ of the prepared extracts. Subsequently, each dish was covered and placed in plastic bags to avoid humidity loss. The petri dishes were placed in the germination chamber at $22 \pm 2{ }^{\circ} \mathrm{C}$ for 120 hours in darkness (US EPA, 1999). Radicles and hypocotyls emerging from seeds were measured with a metric ruler after the germination period. A seed was considered germinated when a radicle structure was visible after which the dishes were placed in a freezer at $-3{ }^{\circ} \mathrm{C}$; After defrosting the dishes, the biological material had a soft consistency, facilitating measurements on radicle and hypocotyl. Germination index (GI) was calculated according to Tiquia and Tam (2000). The same process was done with Lolium perenne $\mathrm{L}$.

\subsection{Analytical methods}

Physical and chemical characterizations of the sludge and soil samples were performed in the laboratories of the Department of Soil and Natural Resources of the University of Concepción.

Paper pulp sludge and soil samples were analyzed according to Sadzawka et al. (2005) and Sadzawka et al. (2006), respectively. Waste $\mathrm{pH}$ was determined in a sludge/water solution (equivalent to 1:5). Soil $\mathrm{pH}$ was determined in a soil/water solution (equivalent to 1:2.5). Total nitrogen in all samples was determined by semi-micro Kjeldahl. Heavy metals (As, $\mathrm{Cd}, \mathrm{Cu}, \mathrm{Pb}, \mathrm{Hg}, \mathrm{Ni}$, Se and $\mathrm{Zn}$ ) were determined by flame atomic absorption spectrometry (Perkin-Elmer spectrometer, model 1100B, Phoenix, Arizona, USA); Organic carbon by Walkley-Black wet digestion; and extractable phosphorus in $0.5 \mathrm{M} \mathrm{NaHCO}_{3}$ (Olsen-P) using the molybdate ascorbic acid method. $\mathrm{Ca}, \mathrm{Mg}$, $\mathrm{K}$ and $\mathrm{Na}$ were determined in $1 \mathrm{~N} \mathrm{NH}_{4} \mathrm{OAc}$ by flame emission spectrometry and EDTA titration. Mn and Fe were determined by flame atomic absorption spectrometry and $\mathrm{HNO}_{3}-\mathrm{HCl}$ digestion. $\mathrm{Al}$ was extracted with a solution of $\mathrm{KCl} 1 \mathrm{M}$ and detected by atomic absorption spectrometry.

\subsection{Statistical analysis}

Germination data were processed by means of variance analysis ANOVA, and comparisons of means were performed according to Tukey's test. Statistical comparison was made with a $95 \%$ significance level ( $p \leq 0.05$ ). The values were processed by statistical trail software GraphPad Prism 5 for Windows (GraphPad Software, Inc.).

\section{Results and discussion}

The Alfisol chemical analysis showed that some nutrient values were below the parameters of what is considered a fertile soil (Carrasco et al., 2002; Vidal, 2007): organic matter (OM) between $1-3 \%$, available $\mathrm{N}\left(\mathrm{NO}_{3}+\mathrm{NH}_{4}\right)<11$ ppm, Olsen-P $(<5 \mathrm{ppm}), \mathrm{S}_{-} \mathrm{SO}_{4}<$ $4 \mathrm{ppm}, \mathrm{B}$ between 0.1-0.3 ppm, indicating an eroded soil in need of an amender. Celis et al. (2007) studied the use of organic wastes on degraded Alfisol soil, whose parameters were slightly different from the results presented here; nonetheless, both researches showed that acidic soils have a tendency towards low $\mathrm{OM}$ and Olsen-P values.

Initial characteristics of paper pulp sludge shown in Table 1 indicates that it presented neutral $\mathrm{pH}$ (7.26), high OM (> $6 \%)$, Olsen-P ( $\geq 30.1$ ppm), S-SO 4 ( 25 
ppm), available $\mathrm{K}\left(\geq 0.65 \mathrm{cmol} \mathrm{kg}^{-1}\right)$ and $\mathrm{Ca}(\geq 15.01$ $\mathrm{cmol} \mathrm{kg}^{-1}$ ), suggesting that the waste could be used as a soil amender. The high concentrations of metals, $\mathrm{Fe}$ ( $>4.51 \mathrm{ppm}), \mathrm{Mn}(>1 \mathrm{ppm}), \mathrm{Zn}(>1 \mathrm{ppm}), \mathrm{Mg}$ $\left(\geq 2.01 \mathrm{cmol} \mathrm{kg}^{-1}\right)$ and $\mathrm{Cu}$ ( $\left.>0.5 \mathrm{ppm}\right)$ (Carrasco et al., 2002; Vidal, 2007), correspond to the quantities in a pure sample; in this study, diluted samples were used and hence these numbers does not represent a risk of potential toxicity. Heavy metals contents were also determined: $\mathrm{As}(<40 \mathrm{ppm}), \mathrm{Cd}(<40 \mathrm{ppm}), \mathrm{Cu}$ (<1200 ppm), $\mathrm{Hg}(<20 \mathrm{ppm}), \mathrm{Ni}(<420 \mathrm{ppm}), \mathrm{Pb}$ $(<400 \mathrm{ppm}), \mathrm{Se}(<100 \mathrm{ppm})$ and $\mathrm{Zn}(<2800 \mathrm{ppm})$. According to Supreme Decree No 4/2009 for land application of sludge from municipal wastewater, these results indicate no excesses of these elements in mud applied to a degraded soil.

With regard to the physical properties, the bulk density $(0.598 \mathrm{~g} \mathrm{~cm}-3)$ of the sludge is considerably lower than that of the soil (1.5 g cm-3) which suggests that the waste porosity is greater, favoring water accumulation and gas exchange (García-Orenes et al., 2005). This result is consistent with the results obtained by Sandoval et al. (2011) where sewage sludge was used as a soil amender, proving that the contribution of soil organic matter to waste is to decrease the bulk density and increase the total porosity. Moreover, usable sludge moisture (20.4\%) significantly increase to $150 \%$ (higher than usable soil moisture of $7.8 \%$ ), resulting in an efficient use of water resource due to the greater moisture retention capacity of the sludge. This is in good agreement to the research of Esparza (2004) who determined that paper pulp sludge added to Andisol soils also improves the moisture retention capacity.
Table 1. Initial chemical properties (dry-weight basis) of Alfisol soil samples (AS) and paper pulp sludge samples (PPS).

\begin{tabular}{|c|c|c|}
\hline Samples & AS & PPS \\
\hline $\mathrm{pH}$ & 6.16 & 7.26 \\
\hline $\mathrm{OM}(\%)$ & 2.00 & 25.31 \\
\hline \multicolumn{3}{|c|}{ ppm } \\
\hline available $\mathrm{N}$ & 10.80 & 19.95 \\
\hline Olsen-P & 2.00 & 50.48 \\
\hline $\mathrm{SO}_{4}-\mathrm{S}$ & 2.60 & 1187.38 \\
\hline $\mathrm{Fe}$ & 18.4 & 44.95 \\
\hline $\mathrm{Mn}$ & 28.2 & 63.70 \\
\hline $\mathrm{Zn}$ & 0.80 & 10.65 \\
\hline $\mathrm{Cu}$ & 1.10 & 2.35 \\
\hline B & 0.10 & 0.43 \\
\hline As & - & 2.80 \\
\hline $\mathrm{Cd}$ & N.D. & N.D. \\
\hline $\mathrm{Hg}$ & N.D. & N.D. \\
\hline $\mathrm{Ni}$ & - & 26.45 \\
\hline $\mathrm{Pb}$ & - & 10.94 \\
\hline $\mathrm{Se}$ & - & 0.10 \\
\hline \multicolumn{3}{|c|}{$\mathrm{cmol} \mathrm{kg}^{-1}$} \\
\hline available $\mathrm{K}$ & 0.41 & 0.65 \\
\hline $\mathrm{Ca}$ & 5.0 & 27.30 \\
\hline $\mathrm{Mg}$ & 1.42 & 3.13 \\
\hline $\mathrm{Na}$ & 1.42 & 0.60 \\
\hline $\mathrm{Al}$ & 0.01 & 0.02 \\
\hline $\mathrm{EC} \mathrm{dS} \mathrm{m}{ }^{-1}$ & 0.01 & 1.93 \\
\hline Ratio $\mathrm{C} / \mathrm{N}$ & - & 87.25 \\
\hline
\end{tabular}

OM: Organic Matter; $\mathrm{N}$ available: $\mathrm{NH}_{4}-\mathrm{N}+\mathrm{NO}_{3}-\mathrm{N}$;

ND: not detected. 
Table 2. Chemicals properties of Afisol soil ( $\mathrm{T})$ pulp paper sludge (PPS) and soil/sludge treatments $\left(\mathrm{T}_{1}=10 \mathrm{t} \mathrm{ha}^{-1}\right.$, $\left.\mathrm{T}_{2}=25 \mathrm{tha}^{-1}, \mathrm{~T}_{3}=50 \mathrm{tha}^{-1}, \mathrm{~T}_{4}=75 \mathrm{tha}^{-1}, \mathrm{~T}_{5}=100 \mathrm{tha}^{-1}, \mathrm{~T}_{6}=150 \mathrm{tha}^{-1}\right)$ after 15 days of incubation.

\begin{tabular}{|c|c|c|c|c|c|c|c|c|c|c|c|c|c|c|c|}
\hline Treatments & $\mathrm{pH}$ & OM & $\begin{array}{c}\text { Usable } \\
\text { Moisture }\end{array}$ & $\begin{array}{c}\mathrm{N} \\
\text { available }\end{array}$ & Olsen-P & $\mathrm{SO}_{4}-\mathrm{S}$ & $\mathrm{Zn}$ & $\mathrm{Cu}$ & B & $\underset{\text { available }}{\mathbf{K}}$ & $\mathrm{Ca}$ & Mg & $\mathrm{Na}$ & Al & EC \\
\hline$(\%)$ & & & & ppm & & & & & & cmol kg ${ }^{1}$ & & & & & $\mathbf{d S} \mathbf{m}^{-1}$ \\
\hline $\mathrm{T}$ & 5.60 & 1.97 & 4.0 & 32.70 & 4.40 & 1.20 & 0.70 & 1.10 & 0.10 & 0.47 & 4.59 & 1.61 & 0.05 & 0.01 & 0.1 \\
\hline PPS & 7.28 & 24.55 & 25.9 & 12.60 & 48.60 & 896.70 & 15.80 & 3.60 & 0.80 & 0.87 & 33.80 & 4.69 & 17.01 & 0.03 & 4.0 \\
\hline $\mathrm{T}_{1}$ & 6.07 & 2.23 & 5.5 & 45.90 & 5.30 & 11.00 & 0.80 & 1.10 & 0.40 & 0.42 & 4.72 & 1.41 & 0.14 & 0.01 & 0.1 \\
\hline $\mathrm{T}_{2}$ & 6.26 & 2.06 & 5.4 & 55.30 & 6.30 & 19.30 & 0.90 & 1.10 & 0.20 & 0.45 & 5.78 & 1.55 & 0.2 & 0.06 & 0.2 \\
\hline $\mathrm{T}_{3}$ & 6.76 & 3.15 & 5.0 & 38.40 & 5.90 & 13.70 & 0.90 & 1.10 & 0.10 & 0.45 & 6.68 & 1.51 & 0.26 & 0.01 & 0.2 \\
\hline $\mathrm{T}_{4}$ & 7.23 & 3.16 & 5.0 & 29.00 & 6.30 & 39.60 & 1.10 & 1.10 & 0.10 & 0.44 & 8.16 & 1.57 & 0.41 & 0.01 & 0.2 \\
\hline $\mathrm{T}_{5}$ & 7.31 & 2.79 & 5.3 & 23.50 & 6.10 & 48.40 & 1.10 & 1.10 & 0.10 & 0.43 & 8.93 & 1.61 & 0.53 & 0.01 & 0.3 \\
\hline $\mathrm{T}_{6}$ & 7.59 & 3.08 & 5.0 & 27.80 & 8.8 & 62.00 & 1.30 & 1.00 & 0.10 & 0.46 & 11.37 & 1.67 & 0.76 & 0.01 & 0.3 \\
\hline Limit $^{1}$ & $\begin{array}{l}6.5- \\
7.3\end{array}$ & $3-6$ & - & $\begin{array}{l}21.0- \\
36.0\end{array}$ & $\begin{array}{l}10.1- \\
20.0\end{array}$ & $\begin{array}{l}10.0- \\
16.0\end{array}$ & $\begin{array}{c}0.5- \\
1.0\end{array}$ & $\begin{array}{c}0.3- \\
0.5\end{array}$ & $\begin{array}{l}0.5- \\
1.0\end{array}$ & $\begin{array}{l}0.25- \\
0.51\end{array}$ & $\begin{array}{l}5.0- \\
9.0\end{array}$ & $\begin{array}{c}0.51- \\
1.01\end{array}$ & $\begin{array}{c}0.21- \\
0.30\end{array}$ & $\begin{array}{c}0.25- \\
0.50\end{array}$ & - \\
\hline
\end{tabular}

OM: Organic matter; $\mathrm{N}$ available: $\mathrm{NH}_{4}-\mathrm{N}+\mathrm{NO}_{3}-\mathrm{N}$

1. Nutrient availability Medium Category in soil according to Carrasco et al. (2002) and Vidal (2007).

From the soil and sludge/soil treatment analysis after 15 days of incubation, shown in Table 2, it was possible to identify that the soil acidity decreased when a higher waste dose was added, in conformity with the study by Torkashvand et al. (2010). Thus, at $150 \mathrm{t}$ $\mathrm{ha}^{-1}$ of mud, the soil $\mathrm{pH}$ increased 1.39 times, an important data to consider when amending eroded acid forest soils. Aravena et al. (2007) obtained similar results after 15 days of incubation during the treatment of volcanic soils with pulp sludge; however, the $\mathrm{pH}$ values decreased at day 75 of incubation. In addition, this $\mathrm{pH}$ increase which is due to the different bases, especially $\mathrm{Ca}^{+}$in this case (Millán et al., 2010), did not have negative effects on nutrient availability in this study. In treatments with $>50 \mathrm{t} \mathrm{ha}^{-1}$ of added sludge, OM increased an average of $1 \%$. Considering that more than a $100 \%$ of the initial OM was added to the soil, this was interpreted as positive because an increase in $\mathrm{OM}$ levels improves moisture retention and soil structural stability through the formation of aggregates (Sandoval et al., 2010). This increase is statistically significant $(p \leq 0.05)$ which is in agreement to the results obtained by Aravena et al. (2007) who determined that an addition of $54 \%$ of $\mathrm{OM}$ to the soil causes major changes. Quantity levels of available nitrogen (nitrate and ammonium) in the soil increased from $2 \%$ to $32.7 \%$ mainly due to the incubation process, while sludge addition increased this value to $55.3 \%$ for a dosage of $25 \mathrm{t} \mathrm{ha}^{-1}$. In relation to concentrations of available $\mathrm{N}$, it increased for a $50 \mathrm{t} \mathrm{ha}^{-1}$ dosage to the soil, similar to results obtained by Aravena et al. (2007). Although greater 
amounts of added waste to soil resulted in a decrease of $\mathrm{N}$ availability, the percentage of the element in all sludge/soil treatments were maintained at a medium level according to the nutrient categories in soil proposed by Riquelme et al. (2004); thus, these results also suggest neither lixiviation nor underground water contamination will exist as well as no occurrence of toxicity due to nitrate surplus (Antimán and Martínez, 2005). Phosphorous levels increased in all treatments where waste was supplemented to the soil; however, the concentrations reached are still low considering the availability of the nutrient in the soil (Carrasco et al., 2002). Nonetheless, this input is interesting as this element in Chile is usually added to soil as an inorganic fertilizer which is imported with an associated cost (Espinoza, 2009). Calcium presented a similar behavior, increasing its concentration as much as mud was supplemented and surpassing the middle rank for the element concentration in the soil (Carrasco et al., 2002; Riquelme et al., 2004). Magnesium concentration also tended to augment to added sludge doses to soil, surpassing a middle level for the element as shown in Table 2. However, a measure of suitability of organic residues as a nutrient source for plant growth (deduced from the ratio of the contents of $\mathrm{Ca}$ to $\mathrm{Mg}$ ) is generally accepted at a minimum ratio of 6:1 (Nunes et al., 2008). In these treatments, the ratio increased from $3.35\left(\mathrm{~T}_{1}\right)$ to 6.81 $\left(\mathrm{T}_{6}\right)$, suggesting that despite the high concentrations of $\mathrm{Ca}$ and $\mathrm{Mg}$ in the soil, this might be beneficial to plant growth. Sodium was present in high concentration in all treatments where paper sludge was added to the soil in comparison to the control; no value was higher than the initial concentration in the soil before sludge/soil incubation. This initial quantity shown in Table 1 surpass the nutrient concentration limit in a medium category; thus the effect of sludge in the soil was found to be positive since it decreased the excess $\mathrm{Na}$ (Carrasco et al., 2002; Riquelme et al., 2004). Sulfate presented the highest values, considerably surpassing the maximum concentration limit in Alfisol soils at $150 \mathrm{t} \mathrm{ha}^{-1}$ of sludge; however, when 10 and $50 \mathrm{t} \mathrm{ha}^{-1}$ were added, the sulfate level stayed within the acceptable parameters for soil nutrition (Riquelme et al., 2004). Regarding $\mathrm{Fe}$ and Mn, suitable levels of these elements were observed for plant growth and a decrease occurred while the amount of waste increased, as shown in Figure 1. This is beneficial because elevated levels of Fe and $\mathrm{Mn}$ and the absence of oxygen could cause toxicity problems. This is in accordance with results obtained by Torkashvand et al. (2010) who demonstrated that increased doses of paper mill sludge resulted in decreased concentrations of these elements in the soil. $\mathrm{Zn}$ values increased with increasing doses of mud. The concentration at $50 \mathrm{t} \mathrm{ha}^{-1}$ of sludge, however, was maintained in the medium category according to Carrasco et al. (2002) and Riquelme et al. (2004). Similar results were found by Gallardo et al. (2012) who also determined an inverse correlation between the concentration of $\mathrm{Zn}$ and the $\mathrm{pH}$ of the soil, suggesting that increased $\mathrm{pH}$ diminishes the availability of $\mathrm{Zn}$ to plant. All the sludge/soil treatments including the control resulted in an increase in the availability of $\mathrm{K}$ in comparison to the initial concentration in the Alfisol soil shown on Table 1; the quantities that were within acceptable limits (Carrasco et al., 2002; Riquelme et al., 2004). The concentration of B and $\mathrm{Al}$ remained below the medium category, while that of $\mathrm{Cu}$ was over the medium category. (Riquelme et al., 2004). 


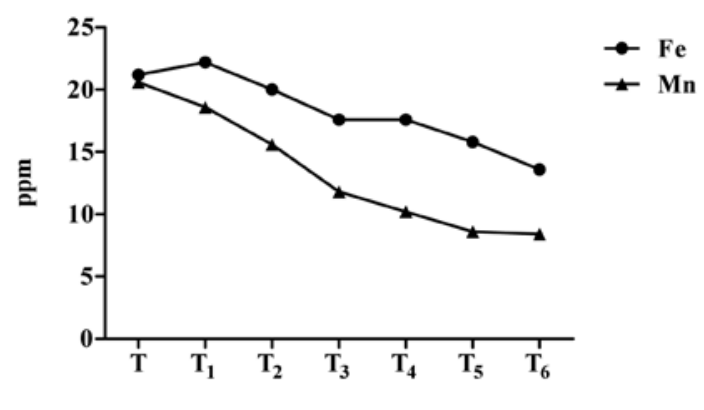

Treatments

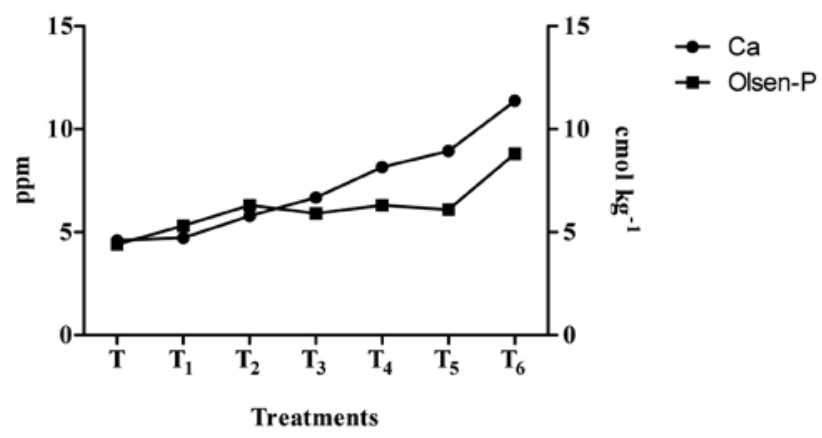

Figure 1. Nutrients of the Alfisol soil $(0-20 \mathrm{~cm})$ and the amended soil with biosolids at different doses: $\mathrm{T}=\mathrm{AS}$, $\mathrm{T} 1=10 \mathrm{t}$ ha-1, T2=25 $\mathrm{t}$ ha-1, T3=50 $\mathrm{t}$ ha-1, T4=75 $\mathrm{t}$ ha-1, T5=100 $\mathrm{t}$ ha- 1 and $\mathrm{T} 6=150 \mathrm{t}$ ha-1; after 15 days of incubation.

\subsection{Lactuca sativa L. and Lolium perenne L.} toxicity assays

According to germination assays performed with Lactuca sativa L., there were no significant differences $(p \leq 0.05)$ in the Germination Index (GI) among the different treatments of the sludge/soil samples (Figure 2). The greatest value (155\%) was obtained when germination was performed in the soil sample, and the highest value for GI in sludge/ soil samples was at a rate of $150 \mathrm{t} \mathrm{ha}^{-1}$ with $142 \%$. All sludge/soil treatments showed GI values greater than $120 \%$ which is positive considering values over $80 \%$ show non-toxic sludge, according to Zucconi et al. (1981). Bioassays performed in lettuce seeds by Celis et al. (2007) with different organic wastes (municipal and salmon industry) in Alfisol soil had similar GI results, although none of the treatment 
had values greater than $120 \%$ as in this study. On the contrary, bioassays performed with Lolium perenne L. showed significant differences $(p \leq 0.05)$ of GI among treatments (Figure 2). The greatest value (137\%) was obtained when germination was performed at a dose of $50 \mathrm{t} \mathrm{ha}^{-1}$ and all sludge/soil tests showed GI values higher than $80 \%$. This result is in contrast to the investigation performed by Gallardo et. al. (2010) in which GI of ryegrass only reached $43 \pm 3.2 \%$ when sludge from kraft mill wastewater was added to volcanic soil at a maximum dose of $50 \mathrm{tha}^{-1}$, indicating the more profound effect of the physical and chemical properties of both soil and the waste over the seed germination.

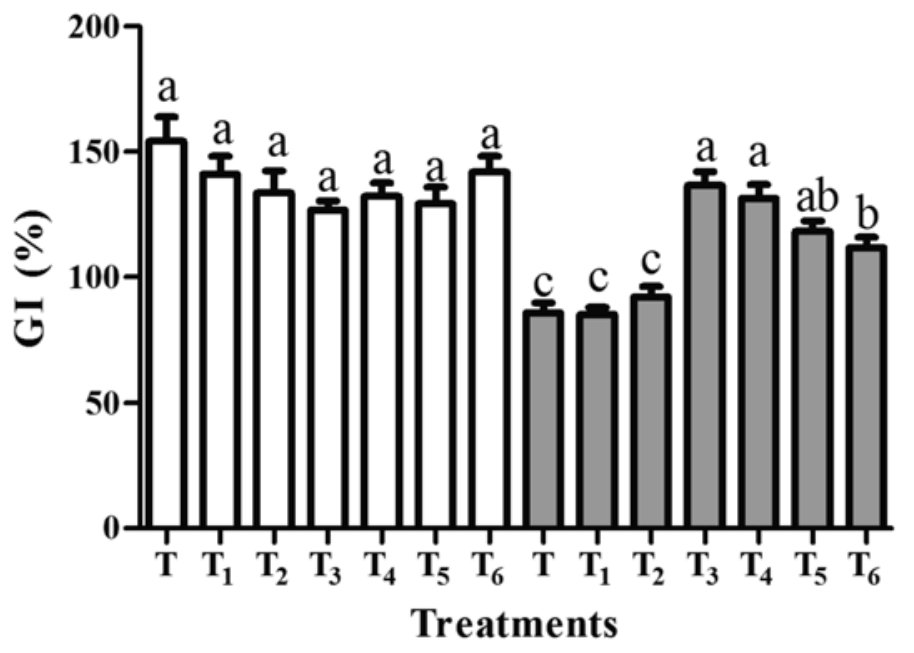

$\square$ Lactuca sativa L. $\square$ Lolium perenne L.

Figure 2. Effect of paper pulp sludge addition to Alfisol soil at different doses: $\mathrm{T}=\mathrm{AS}, \mathrm{T}_{1}=10 \mathrm{tha}^{-1}, \mathrm{~T}_{2}=25 \mathrm{tha}^{-1}$, $\mathrm{T}_{3}=50 \mathrm{tha}^{-1}, \mathrm{~T}_{4}=75 \mathrm{tha}^{-1}, \mathrm{~T}_{5}=100 \mathrm{tha}^{-1}$ and $\mathrm{T}_{6}=150 \mathrm{t} \mathrm{ha}^{-1}$; on germination index (GI) for Lactuca sativa $\mathrm{L}$. and Lolium perenne $\mathrm{L}$. seeds. Bars with the same letter did not differ significantly $(p \leq 0.05)$. 


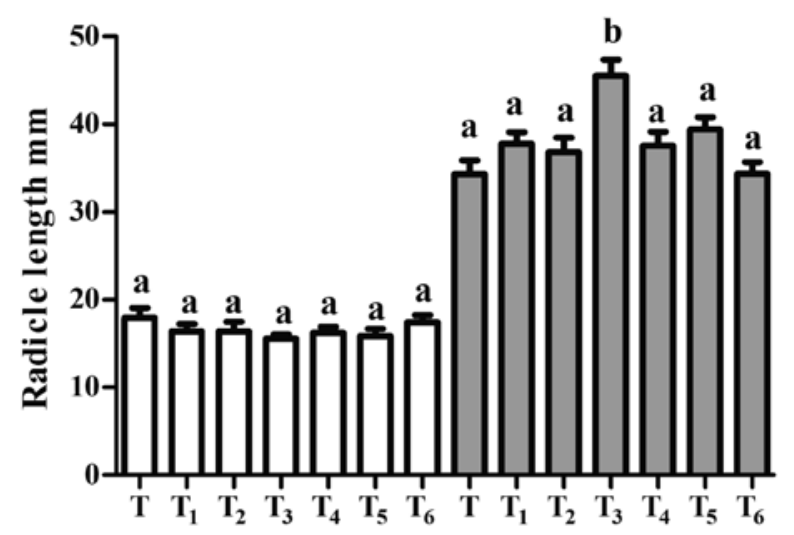

Treatments

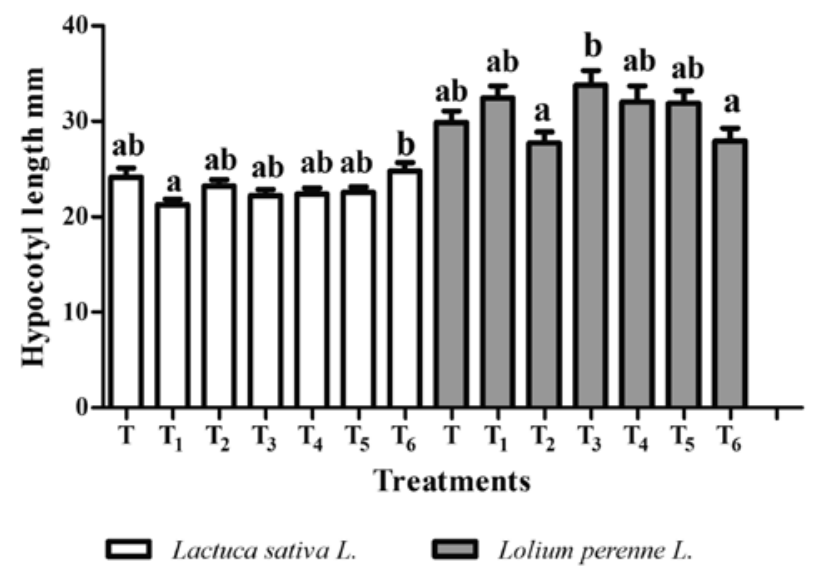

Figure 3. Effect of pulp paper sludge addition to Alfisol soil with different doses: $\mathrm{T}=\mathrm{AS}, \mathrm{T}_{1}=10 \mathrm{t} \mathrm{ha}^{-1}, \mathrm{~T}_{2}=25$ $\mathrm{t} \mathrm{ha}^{-1}, \mathrm{~T}_{3}=50 \mathrm{tha}^{-1}, \mathrm{~T}_{4}=75 \mathrm{tha}^{-1}, \mathrm{~T}_{5}=100 \mathrm{t} \mathrm{ha}^{-1}$ and $\mathrm{T}_{6}=150 \mathrm{t} \mathrm{ha}^{-1}$; on radicle and hypocotyl length for Lactuca sativa L. and Lolium perenne L. seeds. Bars with the same letter did not differ significantly $(p \leq 0.05)$.

Figure 3 shows the results of radicle and hypocotyl length for Lactuca sativa $\mathrm{L}$. Sludge/soil treatments did not negatively affect seed development. The highest value for the radicle length was obtained when seeds were germinated in the control $(18 \mathrm{~mm})$ and the lowest value was when $50 \mathrm{t} \mathrm{ha}^{-1}$ of sludge was added $(15.6 \mathrm{~mm})$, without significant differences $(p \leq 0.05)$.
The development of the Hypocotyl, however, showed significant differences $(p>0.05)$ between treatment $\mathrm{T}_{6}$ and $\mathrm{T}_{1}$, reaching an average length of $24.8 \mathrm{~mm}$ at the higher dose added of $150 \mathrm{t} \mathrm{ha}^{-1}$. In other work, lettuce seed development in Alfisol soil with different doses of different organic wastes reached higher values for radicle length $(>25 \mathrm{~mm})$ and similar values 
for hypocotyl length (between 20-30 mm) (Celis et al., 2007). This could be due to the fact that the characteristics of the degraded soil and the wastes used as fertilizer were different in both studies; however, when comparing our different sludge treatments to the control in this experiment, it indicates no phytotoxic effects using paper pulp sludge.

Results in Figure 3 with Lolium perenne L. show a significant difference $(p>0.05)$ in treatment $\mathrm{T}_{3}$ when the maximum value for radicle length reached $(45.5 \mathrm{~mm})$. In results for hypocotyl length there were also significant differences $(p>0.05)$ between treatment $\mathrm{T}_{3}$ and treatments $\mathrm{T}_{2}$ and $\mathrm{T}_{6}$, resulting in a length of $33.8 \mathrm{~mm}$ when $50 \mathrm{t} \mathrm{ha}^{-1}$ was added to soil.

\section{Conclusions}

Sludge application in Alfisol soil resulted in increases of Organic Matter, Olsen-P, $\mathrm{S}_{-} \mathrm{SO}_{4}, \mathrm{Zn}$ and $\mathrm{pH}$ levels in all treatments where sludge was added, as well as decreases in Fe and Mn, suggesting that sludge is a capable product to improve fertility conditions of degraded soils. Bioassays preformed in Lactuca sativa L. and Lolium perenne L. seeds indicate there is no phytotoxicity effect related to sludge application and the waste added to the soil presented a tendency to improve germination index and radicle and hypocotyl development. Treatment $\mathrm{T}_{3}\left(50 \mathrm{tha}^{-1}\right.$ of sludge added to soil) presented in Lolium perenne a significant difference in all the measured variables in the phytotoxic assay in benefit for the plant growth. Therefore, according to the results, paper sludge has a potential use as soil improver.

\section{Acknowledgments}

This research was funded by the Technology Development Unit of the University of Concepción.

\section{References}

Antimán, M. and Martínez, E. 2005. Grado de antropización, evaluación y modelación matemática del nivel trófico del lago Budi como base para determinar su comportamiento ambiental. Degree thesis, Catholic University of Temuco, Chile. 200 p.

Aravena, C., Valentin, C., Diez, M., Mora, M. and Gallardo, M. 2007. Aplicación de lodos de planta de tratamiento de celulosa: efectos en algunas propiedades físicas y químicas de suelos volcánicos. J. Soil Sc. Nutr. 7(1): 1-14.

Carrasco, J., Squella, F. and Undurraga, P. 2002. Prácticas para el manejo sustentable de los recursos naturales en la recuperación de los suelos degradados. INIA Rayentué. 148 p.

Celis, J., Sandoval, M., Zagal, E., and Briones, M. 2006. Efecto de la adición de biosólidos urbanos y de salmonicultura sobre la germinación de semillas de lechuga (Lactuca sativa L.) en un suelo patagónico R.C. Suelo Nutr. Veg. 6(3):13-25.

Celis, J., Sandoval, M. and Bello, N. 2011. No-linear respiration dynamics in a degraded Alfisol amended with different dose of salmon sludge. J. Soil Sci. Plant Nutr. 11(1): 58-67.

CIREN. 1994. Estudio agrológico VII Región. Descripciones de suelos, materiales y símbolos. Publicación No 117, 660p. Centro de Información de Recursos Naturales (CIREN), Santiago, Chile.

Del Pozo, A. and Del Canto, P. 1999. Áreas agroclimáticas y sistemas productivos en la VII y VIII Regiones. Instituto de Investigaciones Agropecuarias (INIA), Centro Regional de Investigación Quilamapu, Chillán, Chile. Serie Quilamapu $N^{\circ}$ 113, $116 \mathrm{p}$.

Ellies, A. 2000. Soil erosion and its control in Chile An overview. Acta Geológica Hispánica 35 (3-4): 279-284. 
Esparza, J. 2004. Uso de lodo biológico proveniente del tratamiento de efluentes de la industria de la celulosa como mejorador de suelos degradados. Master thesis, La Frontera University, Chile, 79 p.

Espinoza, J. 2009. Fertilizantes en Chile: Coyuntura y Perspectivas. Oficina de Estudios y Políticas Agrarias, Ministerio de Agricultura, Chile, 12 p.

Flores, J., Martínez, E., Espinoza, M., Henríquez, G., Avendaño, P., Torres, P. and Ahumada, I. 2010. Determinación de la erosión actual y potencial de los suelos de Chile, Región del Maule. Ministerio de Agricultura, Centro de Información de Recursos Naturales, Publicación No 147, 50 p.

Fraser, D.S., O'Halloran, K. and Van den Heuvel, M. 2009. Toxicity of pulp and paper solid organic waste constituents to soil organisms. Chemosphere 74: 660-668.

Gallardo, F., Bravo, C., Briceño, G. and Diez, M.C. 2010. Use of sludge from kraft mill wastewater treatment as improver of volcanic soils: Effect on soil biological parameters. R.C. Suelo Nutr. Veg. 10(1): 48-61.

Gallardo, F., Cea, M., Tortella, G.F. and Diez, M.C. 2012. Effect of pulp mill sludge on soil characteristics, microbial community and vegetal production of Lolium Perenne. Journal of Environmental Management 95: S193 - S198.

García-Orenes, F., Guerrero, C., Mataix-Solera, J., Navarro-Pedreño, J., Gómez, I. and MataixBeneyto, J. 2005. Factors controlling the aggregate stability and bulk density in two different degraded soils amended with biosolids. Soil \& Tillage Research 82: 65-76.

Gendebien, A., Ferguson, R., Brink, J., Horth, H., Sulivan, M., Davis, R., Brunet, F., Dalimier, F., Landrea B., Krack, D., Perot, J. and Orsi, C. 2001. Survey of wastes spread on land. European Commission, Report $\mathrm{N}^{\circ}$ : CO 4953-2.
Honorato, R. and Bonomelli, C. 2002. Suelos degradados y agricultura sustentable. Agronomía y Forestal UC.15: 20-24.

Jokela, J., Rintala J., Oikari A., Reinikainen O., Mutka K. and Nyronen T. 1997. Aerobic composting and anaerobic digestion of pulp and paper mill sludge. Water Science Technology 36(11): 181-188.

Luraschi, M. 2005. Análisis de la cadena productiva de la celulosa y el papel a la luz de los objetivos de desarrollo sostenible: Estudio de Caso Chile. CEPAL, Naciones Unidas. 96 p.

Millán, G., Vásquez, M., Terminiello, A. and Santos, D. 2010. Efecto de las enmiendas básicas sobre el complejo de cambio en algunos suelos ácidos de la Región Pampeana. Ci. Suelo (Argentina) 28(2): 131-140.

Nunes, J., Cabral, F. and López-Piñero, A. 2008. Short-term effects on soil properties and wheat production from secondary paper sludge application on two Mediterranean agricultural soils. Bioresource Technology 99: 4935-4942.

Pérez, C. and González, J. 2001. Diagnóstico sobre el estado de degradación del recurso suelo en el país. Instituto de Investigaciones Agropecuarias, CRI Quilamapu, Chillán. 196 p.

Riquelme, J., Pérez, C. and Yoshikawa, S. 2004. Manejo y prácticas conservacionistas del suelo para un desarrollo sustentable del secano. Boletin INIA N 124. INIA Quilamapu, Chillán. 200 p.

Sadwaska, A., Carrasco, M., Grez, R. and Mora, M. 2005. Métodos de análisis de compost. Centro Regional de Investigación La Platina, Serie $N^{\circ} 34$, Santiago, Chile. 142p.

Sadwaska, A., Carrasco, M., Grez, R. Mora, M., Flores and H. Neaman, A. 2006. Métodos de análisis recomendados para los suelos de Chile. Centro Regional de Investigación La Platina, Serie $\mathrm{N}^{\mathrm{o}} 30$, Santiago, Chile. $164 \mathrm{p}$. 
Sandoval, M., Celis, J., Stolpe, N. and Capulín, J. 2010. Efecto de enmiendas con lodos urbanos y de salmonicultura en la estructura de un Entisol y un Alfisol en Chile. Agrociencia 44: 503-515.

Sandoval, M., Celis, J. and Morales, P. 2011. Structural remediation of an Alfisol by means of sewage sludge amendments in association with yellow Serradela (Ornithopus compressus L.). J. Soil Sci. Plant Nutr. 11(1): 68-78.

Sobrero, M.C. and Ronco, A. 2004. Ensayo de toxicidad aguda con semillas de lechuga (Lactuca sativa L.). Ensayos Toxicológicos y Métodos de Evaluación de Calidad de Aguas, G. Castillo, Ed. Ottawa, Canadá. p: 71-79.

Supreme Decree $N^{\circ}$ 4. 2009. Regulation for the management of sludge generated at treatment sewage water plants. Ministry General Secretariat of the Presidency of the Republic. Environment National Corporation, Chile. 20 p.
Tiquia, M. and Tam, N. 2000. Co-composting of spent pig litter and sludge with forced-aeration. Bioresour. Technol. 72: 1-7.

Torkashvand, A.M., Haghighat, N. and Shadparvar, V. 2010. Effect of paper mill lime sludge as an acid soil amendment. Sci. Res. Essays 5(11): 1301306.

United States Environmental Protection Agency (EPA). 1999. Catalogue of Standard toxicity test for ecological risk assessment. Office of solid wastes and emergency response. Publication \#9345.0-051. Intermittent Bulletin, Volume 2, $\mathrm{N}^{\circ} 2$.

Vidal, I. 2007. Fertirrigación, Cultivos y Frutales. Publicaciones del Departamento de Suelos y Recursos Naturales, Universidad de Concepción. Chillán, Chile. Volumen 1, N² 118 p.

Zuconi, F., Peram, A., Forte, M. and De Bertolidi, M. 1981. Evaluating toxicity of inmature compost. Biocycle 22: 54-56. 
